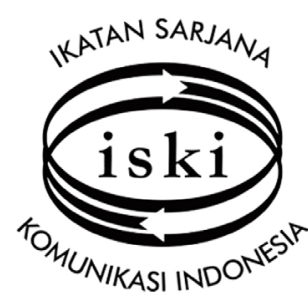

Jurnal Komunikasi. 01 (2016) 64-70

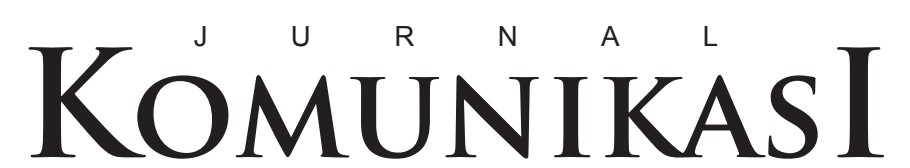

e-ISSN: ---- ------

p-ISSN

IKATAN SARJANA KOMUNIKASI INDONESIA

\title{
IMPLEMENTASI TEORI PLANNED BEHAVIOUR DALAM PENGGUNAAN SIARAN PERS OLEH JURNALIS
}

\author{
Rahmi Nuraini \\ Program Studi Ilmu Komunikasi Universitas Paramadina Jakarta \\ rahminoer@gmail.com
}

\begin{abstract}
Abstrak:
Berdasar survei pendahuluan ditemukan bahwa penggunaan informasi siaran pers oleh jurnalis bervariasi (2\%-100\%). Humas (Public Relation/PR) menjalin kedekatan dengan jurnalis untuk memaksimalkan distribusi informasi, tetapi jurnalis terikat dengan kode etik yang mengatur pekerjaannya. Penelitian ini ingin menjawab strategi apa yang bisa dilakukan PR untuk memaksimalkan publikasi informasi tanpa menyalahi aturan.

Berdasar pengujian implementasi teori Planned Behaviour karya Icek Ajzen ditemukan bahwa, sikap terhadap kualitas siaran pers berpengaruh kuat terhadap niat penggunaan siaran pers, dan akhirnya ikut mempengaruhi perilaku penggunaan siaran pers. Untuk memaksimalkan publikasi, PR dituntut untuk melihat kualitas siaran pers dari perspektif jurnalis.
\end{abstract}

Kata Kunci: Siaran Pers, Perilaku, Jurnalis, Public Relations

\section{PENGANTAR ${ }^{1}$}

Peneliti melakukan survei pendahuluan terhadap enam perusahaan (Bumiputera, TMLI, Andalan Finance, Toyota, Chery dan Merck) melalui 27 publikasi media cetak dalam kurun waktu September 2011 - Mei 2013. Hasilnya jumlah pengutipan release bervariasi dari mulai $2 \%-100 \%$. Selain itu ditemukan bahwa terdapat dua media yang paling sering menggunakan informasi dalam siaran pers sebagai bagian dari tulisannya antara lain Media Indonesia (5 tulisan) dan Bisnis Indonesia (5 tulisan) dalam persentase yang berbeda-beda.

Elvani, PR Officer Toyota dalam wawancara dengan peneliti, membenarkan bahwa ada jurnalis yang menggunakan sebagian informasi dari PR ada juga yang seluruhnya, tergantung kebutuhan jurnalis. Data tentang produk, market, dan investasi juga lebih banyak digunakan dibanding informasi tentang Corporate Social Responsibility (CSR).

Putri, konsultan AsiaPR dalam wawancara dengan peneliti juga menuturkan bahwa publikasi

1 Corresponding author.Email jurnalis dipengaruhi oleh data yang diberikan dalam siaran pers. Jika datanya bagus akan banyak diambil demikian juga sebaliknya. Tugas PR menurut penuturan Putri adalah menyajikan informasi, dan jurnalis memilih sesuai dengan kebutuhannya. Pernyataan yang sama juga disampaikan oleh Fahri, jurnalis Kontan yang membenarkan bahwa dari informasi siaran pers yang banyak diambil adalah informasi terkait data.

Sebagai perwakilan jurnalis, Rofiudin dari Aliansi Jurnalis Independen (AJI) dalam wawancara dengan peneliti juga menuturkan bahwa dalam menjalankan profesinya, jurnalis terikat dengan kode etik. Hal ini membuat ruang gerak jurnalis harus sesuai dengan aturan tersebut, termasuk dalam berhubungan dengan PR. Padahal, PR untuk menjadi dekat dengan jurnalis akan membina hubungan baik dengan jurnalis. Menurut penuturan Selvie, PR Officer Asuransi Bumiputera pada peneliti, kedekatan dengan jurnalis akan memudahkan distribusi informasi dari PR.

Realitas empiris ini memberikan gambaran bahwa jurnalis bekerja berdasar norma dan aturan 
yang menuntut jurnalis terus bersikap profesional. Di sisi lain, PR berharap agar informasi yang disebarkan ke media dapat digunakan secara maksimal. Penelitian ini menjadi berguna karena PR (disebabkan oleh profesinya) tidak dapat secara leluasa menggali lebih dalam tentang kebutuhan jurnalis untuk memaksimalkan fungsi PR. Sehingga peneliti yang independen lebih dapat mengungkap kebutuhan ini, dan di sisi lain jurnalis pun tidak melihat peneliti mempunyai kepentingan sendiri.

Dari hasil riset pendahuluan ditemukan bahwa informasi PR telah digunakan oleh jurnalis meskipun dalam persentase yang kecil. Hal ini membuka peluang PR untuk mengetahui strategi apa yang bisa dilakukan untuk memaksimalkan publikasi informasi melalui penggunaan siaran pers. Untuk mengujinya, konsepsi teori Planned Behavior digunakan untuk memprediksi penggunaan informasi dari siaran pers.

\section{LANDASAN TEORI}

Teori Planned Behavior dari Icek Ajzen menjelaskan dimensi perilaku penggunaan siaran pers oleh jurnalis dipengaruhi sikap, norma subjektif dan kontrol perilaku (Azjen, 1991: 179). Teori Planned Behavior didasarkan pada asumsi bahwa manusia adalah makhluk yang rasional dan menggunakan informasi secara sistematis. Orang memikirkan implikasi dari tindakan mereka sebelum memutuskan untuk melakukan atau tidak melakukan perilaku tertentu. Teori Planned Behavior menyediakan suatu kerangka untuk mempelajari niat untuk perilaku (Littlejohn dan Foss, 2009: 88).

Menurut Ajzen, perilaku dipengaruhi oleh niat, dan niat mempunyai tiga faktor penentu konseptual independen. Pertama, sikap terhadap perilaku yang mengacu pada derajat mana seseorang memiliki evaluasi menguntungkan atau tidak menguntungkan dari perilaku. Prediktor kedua adalah norma subjektif yang mengacu pada tekanan sosial yang dirasakan untuk melakukan atau tidak melakukan perilaku. Anteseden ketiga adalah persepsi pengendali perilaku (kontrol perilaku) yang mengacu pada kemudahan atau kesulitan melakukan perilaku, dan diasumsikan untuk mencerminkan pengalaman masa lalu dan hambatan serta rintangan yang diantisipasi. Secara umum, semakin besar sikap, norma subjektif, dan kontrol perilaku, semakin besar niat seseorang untuk melakukan perilaku (Azjen, 1991: 181-182).

\section{METODOLOGI}

Penelitian eksplanatif ini ingin menjelaskan hubungan sebab akibat di antara beberapa variabel. Populasi penelitian ini adalah jurnalis dari 12 koran nasional yang beredar di Jakarta dan pernah menggunakan informasi dari siaran pers sebagai bahan tulisan berdasar hasil riset pendahuluan.

Jumlah sampel yang digunakan dalam penelitian ini adalah jurnalis dari dua koran yang paling sering menggunakan informasi dari siaran pers sebagai bahan tulisan, yaitu Bisnis Indonesia dan Media Indonesia. Sampel dipilih berdasar kriteria media yang paling sering menggunakan informasi dari siaran pers sebagai bahan tulisan (purposive sampling).

Pengumpulan data dalam penelitian ini dilakukan melalui survei dengan instrumen kuesioner dan wawancara mendalam, yang diperkaya dengan data dari dokumen, arsip, hasil penelitian atau sumber lain yang relevan. Data ini kemudian diolah melalui proses editing, koding, dan tabulasi.

Data ini kemudian dianalisis menggunakan analisis Korelasi Spearman untuk menguji hubungan; analisis Regresi Linier Sederhana untuk menguji pengaruh pengaruh satu variabel terikat terhadap satu variabel bebas; serta analisis Regresi Linear Berganda untuk menguji pengaruh antara beberapa variabel independen terhadap satu variabel dependen. Pengujian menggunakan analisis Jalur (Path Analysis) juga ditambahkan untuk menguji hubungan variabel secara bersamaan, dengan cara terbaik berdasar keterbatasan data yang ada.

\section{HASIL DAN DISKUSI}

Di antara kepercayaan terhadap kualitas siaran pers, kepercayaan terhadap aturan normatif, dan kepercayaan terhadap kedekatan hubungan jurnalis dengan PR, yang mempunyai hubungan terkuat adalah kepercayaan jurnalis terhadap kualitas siaran pers berhubungan dengan kepercayaan terhadap aturan normatif (0.517).

Hubungan ini terjadi karena jurnalis mengembangkan kepercayaan bahwa jurnalis merupakan pekerjaan independen yang mempunyai kebebasan untuk menilai siaran pers mana yang berkualitas dan mana yang tidak. Penilaian jurnalis juga diberikan pada kredibilitas siaran pers. Semakin tinggi kredibilitasnya, jurnalis akan semakin percaya terhadap informasi dalam siaran pers tersebut. Kredibilitas ini dapat berkenaan dengan kelengkapan data, 
ketersediaan kutipan narasumber, informasi latar belakang, contact person, serta kritis tidaknya informasi yang ada dalam siaran pers.

Kepercayaan terhadap kualitas siaran pers sendiri dianalisis dengan melihat evaluasi keuntungan dan kerugian dari siaran pers. Artinya, ketika informasi dalam siaran pers menguntungkan dan memberikan manfaat, jurnalis cenderung akan mengambil informasi tersebut. Demikian juga sebaliknya. Kepercayaan terhadap aturan normatif tidak secara langsung berdampak pada kualitas siaran pers. Dalam kode etik jurnalis maupun aturan media, tidak disebutkan bahwa ada larangan untuk mengutip informasi yang ada dalam siaran pers. Jurnalis bahkan tidak segan mengutip informasi dalam siaran pers ketika deadline maupun ketika ada tugas peliputan yang berkenaan dengan advertorial.

Kode etik jurnalistik bahkan mengatur dan memberikan standar pemberitaan yang baik. Hal ini, secara tidak langsung berhubungan dengan persepsi akan siaran pers yang baik, yaitu siaran pers yang sesuai dengan kebutuhan jurnalis.

Selanjutnya, dibanding sikap terhadap kualitas siaran pers dan kontrol perilaku kedekatan hubungan jurnalis-PR, kepercayaan kuat berpengaruh terhadap norma subjektif (0.929). Kepercayaan terhadap aturan normatif berhubungan dengan pertimbangan penting dari jurnalis untuk menyetujui atau menolak melakukan suatu perilaku. Norma subjektif menjelaskan tentang tekanan yang diterima jurnalis untuk melakukan atau tidak melakukan perilaku.

Dalam teori aturan disebutkan bahwa dengan mengikuti aturan, hasil yang didapatkan akan sesuai. Selain itu aturan memberikan efek yang berbeda tergantung kekuatan dan derajat aturan (Len-Ríos, 2009: 56-65).

Kepercayaan tentangaturan normatifselanjutnya hanya fokus pada apa yang dinilai penting oleh jurnalis. Antara lain mencakup pengaturan tentang independensi jurnalis, objektivitas, akurasi informasi, keberimbangan, iktikad baik, dan larangan menerima amplop. Kesadaran akan adanya konsekuensi yang akan didapat jurnalis jika tidak menaati aturan normatif ini membuat pengaruh Kepercayaan terhadap Aturan Normatif terhadap Norma Subjektif sangat tinggi (73,7\%).

Tingginya pengaruh ini disebabkan karena aturan dalam Kode Etik Jurnalistik (KEJ) dan aturan media menurut teori aturan komunikasi termasuk dalam aturan penghalang dan kewajiban yang mempunyai nilai paksaan yang tinggi (Heath, 2005: 758).

Motivasi untuk patuh dalam hal ini telah menekan pengaruh pada level yang tinggi. Artinya, ketika aturan itu diwajibkan jurnalis tidak mempunyai pilihan lain untuk tidak mematuhi pilihan tersebut. Hasil ini berbeda ketika penelitian dilakukan pada kasus di mana kepercayaan normatif tidak memberikan dampak hukuman bagi subjek penelitian.

Jurnalis mengakui baik di Bisnis Indonesia dan Media Indonesia, beberapa jurnalis merasakan dampak langsung dari pelanggaran aturan tersebut. Konsekuensi yang diberikan disesuaikan dengan jenis pelanggaran, mulai dari pemanggilan, penundaan pangkat, skorsing, pemberian surat peringatan, hingga pemecatan. Pelanggaran yang banyak terjadi adalah plagiarisme dan pemuatan informasi yang tidak valid.

Pelanggaran lain, yang pernah terjadi adalah kebiasaan meninggalkan tugas tanpa ijin, menerima uang, atau mempunyai pekerjaan ganda. Salah satu jurnalis memberikan contoh bahwa ada jurnalis yang mengikuti kegiatan liputan ke luar negeri bersama salah satu perusahaan, padahal jurnalis yang bersangkutan tidak mendapat perintah untuk melakukan peliputan tersebut. Dalam hal ini, jurnalis tersebut dianggap menyalahgunakan kewenangan yang mengatasnamakan perusahaan untuk kepentingan pribadinya.

Setiap ada informasi tentang pelanggaran, cerita tersebut akan berkembang di kalangan jurnalis lain hingga menjadi contoh nyata perlunya kepatuhan terhadap aturan normatif baik yang berkaitan dengan kode etik jurnalistik maupun aturan media.

Dalam menjalankan pekerjaannya, jurnalis terikat dengan dua kepentingan yang terkait erat. Pertama adalah tekanan hati nurani yang tercermin dalam semangat idealisme, yang mendorongnya untuk selalu menyampaikan fakta secara jujur dan objektif. Kedua, adalah kenyataan bahwa jurnalis terikat dengan sejumlah aturan (baik tertulis maupun tidak tertulis) yang mengatur kerja jurnalistik. Dalam menjalankan tugasnya, jurnalis mendapat tekanan untuk menjaga kepatuhan terhadap aturan ini.

Jurnalis meyakini ada dampak yang muncul ketika aturan ini dilanggar mulai dari pemanggilan, penundaan kenaikan jawaban, pengurangan skor, pemberian surat peringatan, hingga pemecatan. Pengaruh yang sama-sama kuat dalam hal ini 
mencerminkan adanya keseimbangan antara hubungan kepercayaan atas aturan normatif dengan kepercayaan atas siaran pers yang berkualitas.

Namun, di antara sikap terhadap kualitas siaran pers, norma subjektif, dan kontrol perilaku, hanya sikap yang mempunyai pengaruh kuat pada niat penggunaan siaran pers. Pengaruh yang dihasilkan mencapai $72,6 \%$. Ketika jurnalis mempunyai sikap yang positif terhadap kualitas siaran pers, motivasi dan usaha jurnalis untuk menggunakan informasi yang ada di dalamnya juga semakin tinggi.

Sebelum memutuskan untuk menggunakan informasi yang ada dalam siaran pers, jurnalis mempunyai pertimbangan personal dan memikirkan pertimbangan tersebut lebih lanjut, hingga sampai pada kesimpulan apakah jurnalis berniat menggunakan siaran pers tersebut atau tidak.

Pertimbangan tersebut mencakup pemenuhan unsur $5 \mathrm{~W}$ dan $1 \mathrm{H}$, ketersediaan data, pemenuhan kutipan narasumber, ketersediaan informasi latar belakang, dan ketersediaan contact person yang bisa dihubungi. Pengaruh pertimbangan tersebut digambarkan dalam grafik 1 .

\section{PANDANGAN JURNALIS-PR TENTANG KUALITAS SIARAN PERS}

Berdasar hasil penelitian diketahui bahwa kepercayaan terhadap kualitas siaran pers mempunyai pengaruh terhadap sikap terhadap kualitas siaran pers $(24,2 \%)$. Namun, kebanyakan jurnalis (27\%) menilai bahwa siaran pers yang dibuat PR cenderung tidak berkualitas. Hal ini menunjukkan bahwa jurnalis mempunyai pemahaman tersendiri terhadap siaran pers yang berkualitas. Perbedaan inilah yang membuat kebanyakan jurnalis menilai bahwa siaran pers yang dibuat PR kurang berkualitas.

Untuk memahami pandangan jurnalis, PR harus melihat dari sisi jurnalis. PR harus memahami seluk beluk dunia media, dan meningkatkan informasi tentang apa yang bisa dilakukan PR untuk memperlancar tugas jurnalis. Jurnalis mempunyai penilaian yang berbeda tentang berita yang bernilai. Misalnya, 23\% jurnalis sepakat bahwa informasi siaran pers sangat penting sekali disesuaikan dengan isu/trend yang sedang berkembang.

Hal ini dapat dijelaskan melalui teori aturan komunikasi yang menyebutkan bahwa individu dan kelompok menerima tujuan melalui komunikasi melalui aturan yang implisit atau eksplisit tentang apa yang harus, tidak harus, seharusnya dan tidak seharusnya dikomunikasikan ke publik untuk mencapai tujuan (Heath, 2005: 758).

Harapan dari redaktur yang menuntut jurnalis mengembangkan tulisan dengan seminim mungkin merujuk pada siaran pers, membuat jurnalis mau tidak mau harus memenuhi tuntutan tersebut. Secara tidak langsung, tuntutan ini berkenaan dengan penilaian redaktur terhadap kualitas jurnalis.

Meskipun demikian, ketersediaan data dalam siaran pers cukup membantu jurnalis. Kesimpulannya, antara jurnalis dan PR saling melakukan penukaran untuk memperoleh pemenuhan informasi. Sesuai dengan konsepsi teori penukaran dari Marwell dan Schmitt (Littejohn, 2005: 179), di mana PR dapat memenuhi pemenuhan dari jurnalis jika mempunyai kekuatan yang cukup dalam konteks sumber dan dapat memberikan yang diinginkan jurnalis. PR mempunyai kekuasaan untuk menentukan nilai, kewajiban dan keduanya.

Grafik 1

Pertimbangan Teknis Penggunaan Siaran Pers

\section{Pertimbangan Teknis Penggunaan Siaran Pers}

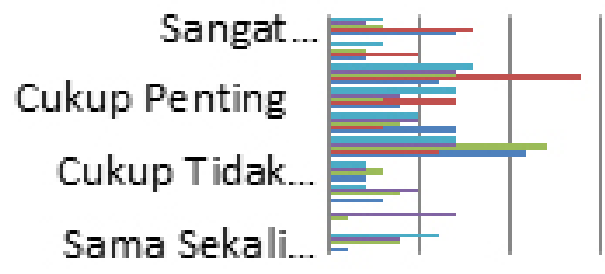

Contact Person

Informasi Latar

Belakang 


\section{CELAH YANG TIDAK DIATUR DALAM KEJ DAN ATURAN MEDIA}

Penggunaan informasi dalam siaran pers, yang tidak diatur dalam KEJ maupun aturan media, semakin menguatkan jurnalis bahwa tindakan tersebut boleh dilakukan. Aturan yang berlaku di media khususnya Bisnis Indonesia dan Media Indonesia juga tidak secara khusus menyebut larangan pengutipan informasi dalam siaran pers. Meskipun demikian, tidak adanya larangan penggunaan informasi ini merupakan pernyataan resmi dari perusahaan. Redaktur hanya memberikan penilaian tambahan bagi jurnalis yang mampu mengembangkan tulisan dan tidak sekedar merujuk atau menyalin siaran pers.

Yang tidak boleh dilakukan jurnalis adalah plagiat, baik dengan mengakui karya orang lain, atau membuat berita yang persis sama dengan karya orang lain. Selain itu, pelanggaran yang sebisa mungkin dihindari jurnalis adalah mengutip informasi yang tidak benar atau menyalahgunakan jabatan untuk kepentingan pribadi.

Celah yang tidak diatur dalam KEJ dan aturan media ini, dapat dimanfaatkan PR untuk memaksimalkan publikasi informasi dalam siaran pers. Salah satunya dengan memberikan informasi yang sesuai dengan kebutuhan jurnalis.

\section{KEDEKATAN DENGAN PR YANG TIDAK DIAKUI}

Meskipun merasa bahwa kedekatan dengan PR penting, jurnalis meyakini bahwa kedekatan hanya diperbolehkan untuk urusan yang berkenaan dengan kegiatan jurnalistik, baik untuk mencari data, melakukan wawancara, hingga pencarian informasi jurnalistik lainnya. Jurnalis merasa perlu dekat dengan PR agar mendapat prioritas dalam akses informasi, agenda acara, dan wawancara narasumber. Jurnalis yang kurang dekat dengan $\mathrm{PR}$, cenderung akan melewati tahap penyeleksian di internal PR sebelum mendapat akses langsung.

Jurnalis juga tidak membenarkan bahwa kedekatan dengan PR berpengaruh terhadap naiknya siaran pers menjadi berita. Namun, jurnalis secara terang-terangan membenarkan bahwa iklan berpengaruh kuat terhadap naiknya siaran pers menjadi sebuah berita. Jurnalis lebih senang menghubungkan digunakannya informasi dalam siaran pes ketika jurnalis tidak hadir dalam sebuah acara, bukan karena alasan lainnya.
Jurnalis lebih fokus pada kemampuan dan pengetahuan PR dalam menyampaikan informasi yang kredibel, akurat dan tepat waktu serta respon yang dibutuhkan. Hubungan antara PR dan jurnalis semakin kuat dan berdampak pada transfer informasi yang baik ketika PR mampu memenuhi harapan jurnalis akan informasi (Deirge, 2008: 228).

Berdasar hasil penelitian, PR yang ideal menurut jurnalis adalah PR yang menguasai konten organisasi dan tidak pelit akan informasi, sayangnya jarang PR yang memahami konten organisasi tempatnya bekerja. Ketika ditanya isu yang lebih besar, PR cenderung tidak bisa menjawab. Seringkali PR mengalami kesulitan untuk merumuskan isi pesan. Karena fakta yang ada di belakang layar kadang-kadang tidak bisa sepenuhnya diolah untuk menjadi isi dan pesan komunikasi. PR cenderung mengemukakan good reason daripada real reason (Tamin, 2011: 76).

Sementara yang jurnalis butuhkan adalah real reason. Pesan-pesan harus mudah dimengerti, yang berarti tidak rumit, bebas jargon, dan mudah ditangkap. Secara sistematis, jurnalis akan menghindari informasi yang memobilisasi dalam tulisan.

Jurnalis juga berharap PR harus mudah dihubungi, fleksibel, atau cepat merespon kebutuhan jurnalis baik berkaitan dengan data atau kebutuhan wawancara dengan narasumber. Jurnalis ingin mendapat akses khusus dari PR, tanpa harus mengajukan surat resmi terlebih dahulu, cukup dengan menelepon atau mengirim email.

Hal ini sejalan dengan pandangan Ivy Lee yang menyatakan bahwa keberhasilan PR sangat tergantung pada kerja sama dengan praktisi jurnalistik. Untuk itu, kesegeraan (promptly) tidak boleh ditinggalkan dalam melayani media. Selain itu, PR juga harus berhubungan dengan jurnalis dengan senang hati (cheerfully). (Tamin, 2011 : 29)

Jurnalis menilai bahwa PR lebih membutuhkan jurnalis dibanding jurnalis membutuhkan PR. Kepercayaan inilah yang berdampak pada pola hubungan yang dikembangkan jurnalis-PR. Terlebih menurut jurnalis, kedekatan dengan PR itu mudah dilakukan karena PR membutuhkan jurnalis. Meskipun demikian, jurnalis tidak mau melakukan inisiatif untuk mendekati PR.

Untuk itu, PR perlu mengembangkan kemampuan komunikasi persuasi. Kemampuan ini berkenaan dengam proses komunikasi interpersonal 
dimana penyampai pesan menggunakan sejumlah simbol untuk mempengaruhi kognisi penerima pesan sehingga menghasilkan efek perubahan sikap. Untuk itu, PR harus mengadopsi prinsip-prinsip persuasi seperti yang dirumuskan oleh J.H. Menning dan C. W.Wilkinson. Salah satunya yaitu dengan menggunakan sudut pandang penerima pesan dan melakukan adaptasi. Dalam konteks penelitian ini, penyesuaian yang bisa dilakukan adalah penyesuaian pembicaraan, bahasa/ gaya bahasa, pengalaman serta cara berfikir yang dimiliki oleh jurnalis.

Pendekatan yang bisa dilakukan PR salah satunya adalah bersikap empati dan integrasi, dengan menyelami situasi yang dialami oleh jurnalis, baik yang berhubungan dengan faktor personal maupun pekerjaan jurnalis tersebut, atau dengan menyatukan situasi yang terbentuk atas dasar kepentingan bersama (Meinanda, 1981: 35).

Pertimbangan lain yang juga mempengaruhi penggunaan informasi dalam siaran pers oleh jurnalis berkenaan dengan konten atau isi dari siaran pers tersebut. Mulai dari pemenuhan news value, kesesuaian dengan kepentingan publik, trend yang berkembang, sisi human interest, kontroversi/ konflik, keunikan, ketersediaan data, dan kesesuaian dengan desk.

Artinya informasi dalam siaran pers yang semakin mendekati kriteria kualitas yang diyakini jurnalis akan lebih berpeluang untuk diambil sebagai bahan tulisan. Hal ini menunjukkan bahwa subsidi informasi dari PR yang memudahkan pekerjaan jurnalis cenderung banyak digunakan. Artinya, praktisi PR perlu mempelajari kebutuhan jurnalis akan nilai berita untuk memperbesar kemungkinan dimuatnya pesan tersebut oleh jurnalis. Niat ini pula yang selanjutnya kuat berpengaruh terhadap perilaku penggunaan informasi dalam siaran pers (56.3\%).

\section{KESIMPULAN}

Setelah dilakukan penelitian, ditemukan beberapa fakta menarik yang dapat memperkaya kajian PR tentang bagaimana cara memaksimalkan publikasi informasi dalam siaran pers. Dalam mengembangkan siaran pers, PR harus melihat informasi dari perspektif jurnalis sehingga dapat memahami apa yang menjadi kebutuhan jurnalis.

Perspektif jurnalis dapat digunakan PR dalam melihat news value, kesesuaian desk jurnalis, pentingnya data terbaru, kesesuaian dengan isu yang berkembang, dan keunikan dari sebuah informasi. PR juga harus mulai mengembangkan informasi lain yang selama ini jarang ditemui dalam siaran pers, seperti halnya informasi yang berhubungan dengan kepentingan publik, mengandung kontroversi atau konflik, dan mengandung human interest. Selain itu, PR juga harus memastikan adanya kelengkapan data, contact person yang jelas, kutipan narasumber yang straight to the point, dan informasi latar belakang yang sesuai dengan kebutuhan jurnalis.

Jika PR tidak dapat memenuhi harapan jurnalis, PR harus menyiapkan data pendukung lain atau akses narasumber yang mampu memberikan data lengkap data pendukung. PR juga dapat menawarkan liputan eksklusif sebagai pengganti informasi siaran pers yang normatif.

Tidak adanya aturan yang mengatur larangan penggunaan informasi dalam siaran pers sebagai bahan tulisan jurnalis dan kedekatan jurnalis dengan PR baik dalam KEJ maupun aturan media, dapat dimanfaatkan PR sebagai celah untuk mendorong publikasi informasi di media massa. Namun, PR harus menghindari pendekatan-pendekatan yang dapat membahayakan reputasi jurnalis karena jurnalis akan bersikap insecure terhadap aturan yang mempunyai konsekuensi berat seperti mendapat surat peringatan hingga dikeluarkan. Aturan ini antara lain mencakup publikasi informasi yang tidak benar, plagiat, atau penyalahgunaan jabatan untuk kepentingan pribadi.

Dalam menjalankan profesinya, PR harus menghormati profesi jurnalis dan kepercayaan jurnalis akan kewajibannya untuk memberikan informasi yang akurat, dilandasi itikad baik, tidak boleh menerima amplop, berimbang, independen, dan objektif. Penghormatan ini dapat dapat dilakukan melalui adaptasi, melalui pendekatan komunikasi persuasi sehingga memudahkan PR mendorong publikasi pesan.

PR harus berinisiatif untuk dekat dengan jurnalis. Karena meskipun mempunyai kemampuan untuk dekat dengan PR, jurnalis cenderung enggan memulai membuka kedekatan dengan PR di luar urusan pekerjaan (kegiatan jurnalistik), seperti pencarian atau konfirmasi data/ agenda acara, hingga permohonan wawancara. Dalam hal ini, jurnalis jarang melakukan inisiatif dekat dengan PR, karena PR tanpa diminta akan mendekati jurnalis untuk kepentingan publikasi berita. 


\section{REFERENSI}

Ajzen, Icek. (2005). Attitudes, Personality, and Behaviour Second Edition. USA: Open University Press

Ajzen, Icek. (1991). The Theory of Planned Behaviour dalam Organizational Behaviour and Human Decision Processes. USA: Academic Press Inc

Ajzen, Icek. (1985). From Intentions to Actions: A Theory of Planned Behavior. Heidelberg: Springer.

Breakendridge, Deirge. (2008). PR 2.0, New Media, New Tools, New Audience. New Jersey: Pearson Education

Heath, Robert L. (2005). Encyclopedia of Public Relations, Volume 2. California: Sage Publucations

Len-Ríos, María E., Amanda Hinnant dan Sun-A Park. (2009). Understanding how health journalists judge public relations sources: A rules theory approach. Review Jurnal Public Relations Review 35

Littlejohn, Stephen W dan Karen A. Foss. (2009). Teori Komunikasi Edisi 9. Jakarta: Salemba Humanika

Meinanda, Teguh. (1981). Pengantar Ilmu Komunikasi Jurnalistik. Bandung: Armico

Tamin, Indrawadi. (2011). Public Relations, Mitos dan Realitas. Jakarta : Universitas Esa Unggul 